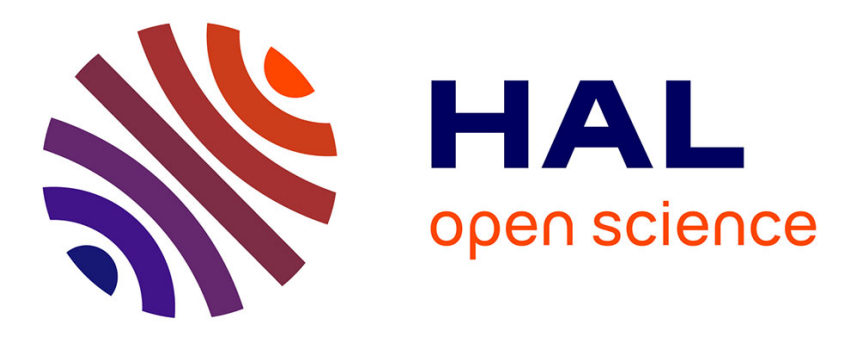

\title{
Multiple-dose pharmacokinetics of telithromycin in peripheral soft tissues
}

Friederike Traunmüller, Rainer Gattringer, Manfred Fille, Christiane Thallinger, Christian Joukhadar

\section{To cite this version:}

Friederike Traunmüller, Rainer Gattringer, Manfred Fille, Christiane Thallinger, Christian Joukhadar. Multiple-dose pharmacokinetics of telithromycin in peripheral soft tissues. International Journal of Antimicrobial Agents, 2009, 34 (1), pp.72. 10.1016/j.ijantimicag.2009.01.016 . hal-00556330

\section{HAL Id: hal-00556330 https://hal.science/hal-00556330}

Submitted on 16 Jan 2011

HAL is a multi-disciplinary open access archive for the deposit and dissemination of scientific research documents, whether they are published or not. The documents may come from teaching and research institutions in France or abroad, or from public or private research centers.
L'archive ouverte pluridisciplinaire HAL, est destinée au dépôt et à la diffusion de documents scientifiques de niveau recherche, publiés ou non, émanant des établissements d'enseignement et de recherche français ou étrangers, des laboratoires publics ou privés. 


\section{Accepted Manuscript}

Title: Multiple-dose pharmacokinetics of telithromycin in peripheral soft tissues

Authors: Friederike Traunmüller, Rainer Gattringer, Manfred

Fille, Christiane Thallinger, Christian Joukhadar

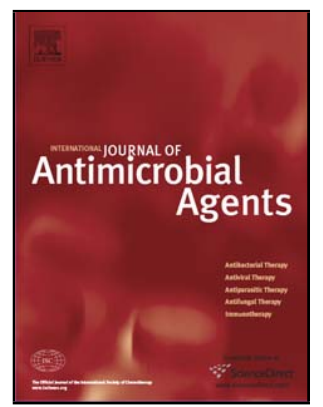

PII:

S0924-8579(09)00062-4

DOI: doi:10.1016/j.ijantimicag.2009.01.016

Reference: ANTAGE 2978

To appear in:

International Journal

of

Antimicrobial

Agents

Received date: $\quad 19-12-2008$

Revised date: $\quad 20-1-2009$

Accepted date: $\quad$ 21-1-2009

Please cite this article as: Traunmüller F, Gattringer R, Fille M, Thallinger C, Joukhadar C, Multiple-dose pharmacokinetics of telithromycin in peripheral soft tissues, International Journal of Antimicrobial Agents (2008), doi:10.1016/j.ijantimicag.2009.01.016

This is a PDF file of an unedited manuscript that has been accepted for publication. As a service to our customers we are providing this early version of the manuscript. The manuscript will undergo copyediting, typesetting, and review of the resulting proof before it is published in its final form. Please note that during the production process errors may be discovered which could affect the content, and all legal disclaimers that apply to the journal pertain. 


\title{
Multiple-dose pharmacokinetics of telithromycin in peripheral soft tissues
}

\author{
Friederike Traunmüller ${ }^{a, b}$, Rainer Gattringer ${ }^{a, c}$, Manfred Fille ${ }^{b}$, Christiane Thallinger \\ b,c , Christian Joukhadar ${ }^{\text {a,c, } 1, *}$ \\ a Department of Clinical Pharmacology, Division of Clinical Pharmacokinetics, \\ Medical University of Vienna, Vienna, Austria \\ ${ }^{\mathrm{b}}$ Medical University of Innsbruck, Innsbruck, Austria \\ ${ }^{\mathrm{c}}$ Department of Internal Medicine I, Medical University of Vienna, Vienna, Austria
}

Received 19 December 2008; accepted 21 January 2009

Keywords: Ketolide; Telithromycin; Multiple doses; Soft tissue infection

* Corresponding author. Present address: J\&P Medical Research Ltd., Vienna 1130, Austria. Tel.: +43 1876 0432-10; fax: +43 1876 0432-33.

E-mail addresses: cjoukhad@bidmc.harvard.edu, christian.joukhadar@jp-medicalresearch.com (C. Joukhadar).

${ }^{1}$ Current addresses: Beth Israel Deaconess Medical Center, 330 Brookline Ave., Boston, MA 02215, USA; Harvard Medical School, Boston, MA 02115, USA. 


\section{Abstract}

Based on clinicians' expectations of high concentrations of telithromycin (TEL) in tissues, combined with its excellent in vitro antimicrobial characteristics, TEL is casually considered as a potential therapeutic option for the therapy of minor cases of soft tissue or bite-wound infections. To clarify this clinically important issue, the present investigation was carried out to measure the pharmacokinetic profile of TEL in the interstitial space fluid (ISF) of skeletal muscle and subcutaneous adipose tissue by means of the microdialysis technique in ten healthy subjects following repetitive daily doses of $800 \mathrm{mg}$ TEL. These data were compared with free concentrations of TEL determined in plasma. External controls for the present examination were the use of historic, single-dose data collected by our study group utilising identical methods and the same trial subjects. Despite an increase in the median half-life from ca. $3 \mathrm{~h}$ after a single dose to ca. $10 \mathrm{~h}$ at steady-state conditions in all compartments, accumulation of TEL in ISF of soft tissues and plasma was clinically non-relevant. Median free peak concentrations in plasma, skeletal muscle and subcutis were $0.52,0.13$ and $0.19 \mathrm{mg} / \mathrm{L}$, respectively. The median ratios of the tissue to plasma free areas under the concentration-time curves from $0-24 \mathrm{~h}$ (fAUC $_{0-24}$ tissue/fAUC ${ }_{0-24}$ plasma) were 0.27 and 0.58 for muscle and subcutis, respectively $(P>0.05)$. The present multiple-dose investigation of TEL is in line with a previous single-dose study confirming that TEL $800 \mathrm{mg} /$ day may not be optimally effective in the therapy of soft tissue infections. 


\section{Introduction}

Telithromycin (TEL) is the first member of the ketolides, a class of semisynthetic antimicrobials that were developed and introduced into the market to overcome the problem of worldwide increasing macrolide resistance of Gram-positive cocci [1]. Owing to its favourable in vitro antimicrobial spectrum, TEL was suggested as a therapeutic option in minor cases of soft tissue and bite-wound infections, although double-blind trials have not proved this and no indication for treatment of skin infection was ever sought from the US Food and Drug Administration (FDA) or European regulatory agencies [2,3].

TEL has recently been subjected to heavy scrutiny because of serious safety concerns and, as a consequence, the FDA retracted two of three indications in February 2007 [3,4]. Thus, in the USA, TEL is now approved solely for the therapy of community-acquired pneumonia (CAP). Nevertheless, in the USA and elsewhere, offlabel use of TEL is still significant despite all FDA concerns regarding hepatotoxicity and other safety risks [5].

In our initial study, we evaluated the pharmacokinetics (PKs) of TEL in soft tissues in a single oral dose study by use of the microdialysis technique in ten healthy male volunteers [6]. However, in this experiment concentrations in the interstitial space fluid (ISF) of tissues were disappointingly low and hardly matched with clinical data reporting on excellent activity in patients presenting with CAP [7]. This discrepancy was expected to be due to histological differences in the lung compared with subcutaneous adipose tissue and skeletal muscle. In fact, the lung is composed of several key compartments, including epithelial fluid, different levels of bronchi and 
bronchioles, four vascular systems, an interstitial lymphatic system, and the alveolus consisting of pulmonary alveolar macrophages and type I and type II pneumonocytes. Skeletal muscle and subcutaneous adipose tissue, on the other hand, appear to be much less complex from a histological point of view.

Nevertheless, many clinicians are still speculating that clinically relevant concentrations may be reached in the ISF of soft tissues at steady-state conditions. Basically, this is related to PK considerations such as the observation of an increase of plasma half-life from ca. $3 \mathrm{~h}$ after single-dose administration to ca. $10 \mathrm{~h}$ at steadystate conditions $[6,8]$, the biexponential elimination profile of TEL $[6,8]$, its large volume of distribution [8] and a convincing link to data on its efficacy in the therapy of patients presenting with Staphylococcus aureus CAP [7].

\section{Subjects and methods}

The present study investigated the ability of TEL to penetrate into soft tissues following multiple doses in healthy male subjects. A previous investigation employing identical methods and inviting exactly the same subjects was used for comparison and the PK data are presented in Table $1 \mathrm{~A}$.

\subsection{Subjects}

Ten healthy male volunteers (aged 18-40 years) who participated previously in a single-dose study [6] were invited to undergo the same procedure at steady-state conditions following repetitive oral doses of $800 \mathrm{mg} /$ day TEL (Ketek ${ }^{\mathrm{TM}} 800 \mathrm{mg}$ tablets; Sanofi-aventis Inc., Bridgewater, NJ) over 5 days. All volunteers received 
standardised meals on study days and were instructed to avoid caffeine and grapefruit juice during the entire study period.

\subsection{Microdialysis}

On study Day 5, microdialysis was performed as described previously [6]. In brief, a microdialysis probe with molecular mass cut-off of 20000 (CMA12;

CMA/Microdialysis $A B$, Solna, Sweden) was inserted into one thigh muscle and into the subcutaneous adipose tissue at the ventrolateral side of the thigh under aseptic conditions with a guidance cannula. The probe was constantly perfused with Ringer's solution (perfusate) at a flow rate of $1.5 \mu \mathrm{L} / \mathrm{min}$ by means of a precision pump (Precidor; Infors AG, Basel, Switzerland). After a 60-min equilibration period, 800 mg of TEL was administered orally to the fasting volunteers. Subsequently, sampling of microdialysates (dialysate) and venous blood was performed at 20-min intervals from 0-4 $\mathrm{h}$ and then at 30-min intervals for later sampling points. Individual recovery values of TEL were determined by use of the in vivo 'retrodialysis method' [10]. Accordingly, TEL was added at a concentration of $5 \mathrm{mg} / \mathrm{L}$ to the perfusion fluid and its rate of disappearance through the microdialysis membrane was determined in duplicate. The individual recovery was calculated using the equation: Recovery $=1-$ ( $\left.C_{\text {dialysate }} / C_{\text {perfusate }}\right)$, where $C_{\text {dialysate }}$ and $C_{\text {perfusate }}$ are the concentrations of dialysate and perfusate, respectively. All samples were stored at minus $80^{\circ} \mathrm{C}$ until analysis.

\subsection{Sample analysis and calculations}

TEL concentrations in plasma and microdialysates were analysed using a validated high-performance liquid chromatography (HPLC) method [11]. Dialysate concentrations were corrected by the individual in vivo recovery value of the 
respective microdialysis probe using the formula: Concentration $(C)=$ $C_{\text {measured }} /$ recovery. A value of $70 \%$ for plasma protein binding of TEL derived from the literature was used for the present PK calculations [12].

PK calculations were performed using commercially available computer software (Kinetica version 3.0; InnaPhase, Philadelphia, PA). The areas under the concentration-time curves from $0-8 \mathrm{~h}\left(\mathrm{AUC}_{0-8}\right), 0-24 \mathrm{~h}\left(\mathrm{AUC}_{0-24}\right)$ and $0 \mathrm{~h}$ to infinity $\left(\mathrm{AUC}_{0-\infty}\right)$ in plasma and interstitial fluid were calculated by the linear trapezoidal rule.

Wilcoxon's test was used for comparison of the AUCs in plasma, skeletal muscle and subcutis within subjects. A two-sided $P$-value of $<0.05$ was considered significant. Multiple testing for significance was adjusted using the Bonferroni method.

\section{Results}

In vivo recoveries for TEL in microdialysates were $62.0 \pm 4.3 \%$ and $63.4 \pm 1.6 \%$ (mean \pm standard deviation) for skeletal muscle and subcutaneous adipose tissue, respectively.

The main PK data observed previously by our study group after single-dose administration are shown in Table 1A. Data collected in the present investigation following administration of five repetitive doses of TEL $800 \mathrm{mg} /$ day are summarised in Table 1B. The PK profiles in plasma, skeletal muscle and subcutaneous adipose tissue show that steady-state conditions were reached for all compartments investigated. As expected, the peak concentrations of free TEL are somewhat higher in plasma compared with soft tissues. Equilibration of TEL is incomplete between the 
free plasma compartment and the ISF of soft tissues. The plasma PK profile at steady state is in accordance with findings in the scientific literature [8], whilst no data on TEL tissue PKs are available for steady-state conditions. Maximum concentrations $\left(C_{\max }\right)$ and $\mathrm{AUC}_{0-24}$ of free TEL $\left(f A \cup C_{0-24}\right)$ in the ISF of subcutaneous adipose tissue are comparable with corresponding values in skeletal muscle $(P>$ 0.05). The median values for $C_{\max }$ are $0.52,0.13$ and $0.19 \mathrm{mg} / \mathrm{L}$ for free TEL in plasma, skeletal muscle and subcutaneous adipose tissue, respectively. The corresponding half-lives are 8.6, 9.8 and $11.7 \mathrm{~h}$ after multiple doses, respectively. The ratios of the $f A U C_{0-24}$ of TEL in tissues to the $f A U C_{0-24}$ in plasma show considerable variability between subjects, ranging from 0.16 to 1.43 for skeletal muscle and from 0.28 to 1.34 for subcutis. The respective median ratios were 0.27 and 0.58 (Table 1B). These findings were in line with single dose data (Table 1A) derived from historic controls [6].

\section{Discussion}

The present experiment set out to test the ability of TEL to penetrate and accumulate in the ISF of soft tissues. Microdialysis probes were implanted into subcutaneous adipose tissue and skeletal muscle in 10 healthy subjects after 5 consecutive days of oral intake of TEL. Performance of the present study in the same individuals used in a previous single-dose trial of TEL minimises interindividual variability in tissue and plasma PKs. This approach therefore increases the overall value of the present investigation in the given situation of a predefined relatively small sample size of 10 subjects. 
The terminal elimination half-life of TEL in plasma is ca. $3 \mathrm{~h}$ after a single dose $[6,13]$ but increases up to ca. $10 \mathrm{~h}$ at steady state [8]. This phenomenon was also observed in our experimental setting. Against all speculations, we found no clinically and microbiologically relevant accumulation of TEL in the ISF of peripheral tissues following multiple doses compared with single dosage in healthy subjects. This finding is in contrast to previous data demonstrating a significant accumulation of TEL in epithelial lining fluid, bronchial tissue, saliva, tonsils, alveolar macrophages and white blood cells [14-17] and a high clinical efficacy of TEL in patients presenting with CAP [7].

In previous investigations, the P-glycoprotein (P-gp), which is an energy-dependent unspecific pump known to be physiologically located on critical biological membranes all across the human body including the pulmonary blood-gas barrier, was demonstrated to affect intracellular concentrations of macrolides [18]. However, at present, knowledge regarding its relevance on the PKs of TEL in the lung is limited as data in the literature are conflicting in acute and chronic disease and are subject to a large variety of endogenous and exogenous confounders $[19,20]$. In addition, the effect of P-pg on ISF levels of macrolides or TEL has not yet been investigated in subcutaneous adipose tissue and skeletal muscle. However, as high activity and expression of P-gp is unlikely to be observed in subcutaneous adipose tissue and skeletal muscle, it can be assumed that TEL's plasma to ISF equilibrium is not substantially affected by P-gp action.

Against this background, it is important to mention that many previous investigations looked at total drug concentrations after tissue homogenisation, whereas the present study specifically describes the PK profiles of unbound TEL in the ISF of 
subcutaneous adipose tissue and skeletal muscle. Utilisation of biopsy concentration data of drugs known to accumulate intracellularly is causing confusion as this approach clearly overestimates free drug concentrations in the ISF in target tissues.

Although there is circumstantial evidence from other studies of an existing relationship between ISF concentrations in peripheral soft tissues and in lungs for the class of $\beta$-lactams, this association has not been shown for intracellularlyaccumulating antibiotics such as the quinolones, macrolides and TEL [21]. Further clinical investigations are necessary to evaluate this relationship. Utilisation of positron emission tomography combined with the microdialysis method might be an elegant approach to enhance our understanding of TEL tissue PKs [22].

In an attempt to give an estimate of the clinical impact of the present investigation, concentrations of TEL were related to minimum inhibitory concentrations (MICs) of relevant pathogens. Currently, a ratio of the plasma $f A U C_{0-24}$ to the pathogen's MIC of $>3.3$ is considered predictive of clinical outcome following TEL therapy [23,24]. This threshold is predominantly not met for the ISF of soft tissues for relevant Staphylococcus spp. (Table 1). In contrast, streptococci are considered to be highly sensitive to TEL $[2,9]$.

In conclusion, owing to the lack of a significant accumulation of TEL in the interstitium of soft tissues following multiple doses, the present study confirms previous investigations reporting on relatively low concentrations of TEL in the ISF of soft tissues. These data therefore suggest that TEL is most likely a suboptimal choice for the therapy of bacterial soft tissue infections. 
Acknowledgments: Part of these data was presented as an abstract and poster at the 48th Annual Interscience Conference on Antimicrobial Agents and Chemotherapy (ICAAC)/Infectious Diseases Society of America (IDSA) 46th Annual Meeting, 25-28 October 2008, Washington, DC. The authors appreciate all the support received at the Department of Clinical Pharmacology of the Medical University of Vienna, Austria. In particular, they are indebted to Dr Markus Müller for outstanding mentorship. Special thanks also go to Martin Popovic and Drs Martin Brunner, Markus Zeitlinger, Robert Sauermann and Hartmut Derendorf.

Funding: None.

Competing interests: $\mathrm{CJ}$ is a consultant for pharmaceutical companies, managing director and chief operating officer of J\&P Medical Research Ltd., Vienna, Austria, and visiting Associate Professor at the Beth Israel Deaconess Medical Center, Harvard Medical School, Boston, MA. All other authors declare no competing interests.

Ethical approval: The present study protocol was approved by the Ethics Committee of the Medical University of Vienna, Austria. 


\section{References}

[1] Bryskier A. Ketolides-telithromycin, an example of a new class of antibacterial agents. Clin Microbiol Infect 2000;6:661-9.

[2] Goldstein EJ, Citron DM, Merriam CV, Warren Y, Tyrrell K. Comparative in vitro activities of ABT-773 against aerobic and anaerobic pathogens isolated from skin and soft-tissue animal and human bite wound infections. Antimicrob Agents Chemother 2000;44:2525-9.

[3] Scheinfeld N. Telithromycin: a brief review of a new ketolide antibiotic. J Drugs Dermatol 2004;3:409-13.

[4] Shlaes DM, Moellering RC. Telithromycin and the FDA: implications for the future. Lancet Infect Dis 2008;8:83-5.

[5] Gleason PP, Walters C, Heaton AH, Schafer JA. Telithromycin: the perils of hasty adoption and persistence of off-label prescribing. J Manag Care Pharm $2007 ; 13: 420-5$.

[6] Gattringer R, Urbauer E, Traunmüller F, Zeitlinger M, Deghanyar P, Zeleny $P$, et al. Pharmacokinetics of telithromycin in plasma and soft tissues after single-dose administration to healthy volunteers. Antimicrob Agents Chemother $2004 ; 48: 4650-3$.

[7] Shi J, Pfister M, Jenkins SG, Chapel S, Barrett JS, Port RE, et al. Pharmacodynamic analysis of the microbiological efficacy of telithromycin in patients with community-acquired pneumonia. Clin Pharmacokinet 2005;44:31729.

[8] Namour F, Wessels DH, Pascual MH, Reynolds D, Sultan E, Lenfant B. Pharmacokinetics of the new ketolide telithromycin (HMR 3647) administered in 
ascending single and multiple doses. Antimicrob Agents Chemother $2001 ; 45: 170-5$.

[9] Shortridge VD, Zhong P, Cao Z, Beyer JM, Almer LS, Ramer NC, et al. Comparison of in vitro activities of ABT-773 and telithromycin against macrolidesusceptible and -resistant streptococci and staphylococci. Antimicrob Agents Chemother 2002;46:783-6.

[10] Joukhadar C, Müller M. Microdialysis: current applications in clinical pharmacokinetic studies and its potential role in the future. Clin Pharmacokinet 2005;44:895-913.

[11] Traunmüller F, Gattringer R, Zeitlinger MA, Graninger W, Müller M, Joukhadar C. Determination of telithromycin in human plasma and microdialysates by highperformance liquid chromatography. J Chromatogr B Analyt Technol Biomed Life Sci 2005;822:133-6.

[12] Muller-Serieys C, Andrews J, Vacheron F, Cantalloube C. Tissue kinetics of telithromycin, the first ketolide antibacterial. J Antimicrob Chemother 2004;53:149-57.

[13] Edlund C, Gunnar A, Barkholt L, Vacheron F, Nord CE. Pharmacokinetics and comparative effects of telithromycin (HMR 3647) and clarithromycin on the oropharyngeal and intestinal flora. J Antimicrob Chemother 2000;46:741-9.

[14] Gehanno P, Sultan F, Passot V, Nabet P, Danon J, Romanet P, et al. Telithromycin (HMR 3647) achieves high and sustained concentrations in tonsils of patients undergoing tonsillectomy. Int J Antimicrob Agents 2003;21:441-5.

[15] Kadota J, Ishimatsu Y, Iwashita T, Matsubara Y, Tomono K, Tateno M, et al. Intrapulmonary pharmacokinetics of telithromycin, a new ketolide, in healthy Japanese volunteers. Antimicrob Agents Chemother 2002;46:917-21. 
[16] Khair OA, Andrews JM, Honeybourne D, Jevons G, Vacheron F, Wise R. Lung concentrations of telithromycin after oral dosing. J Antimicrob Chemother 2001;47:837-40.

[17] Pascual A, Ballesta S, Garcia I, Perea FJ. Uptake and intracellular activity of ketolide HMR 3647 in human phagocytic and non-phagocytic cells. Clin Microbiol Infect 2001;7:65-9.

[18] Seral C, Michot J, Chanteux H, Mingeot-Leclercq M, Tulkens PM, VanBambeke F. Influence of P-glycoprotein inhibitors on accumulation of macrolides in $\mathrm{J774}$ murine macrophages. Antimicrob Agents Chemother 2003;47:1047-51.

[19] Lechapt-Zalcman E, Hurbain I, Lacave R, Commo F, Urban T, Antoine M, et al. MDR1-Pgp 170 expression in human bronchus. Eur Respir J 1997;10:183743.

[20] van der Deen M, Marks H, Willemse BW, Postma DS, Muller M, Smit EF, et al. Diminished expression of multidrug resistance-associated protein 1 (MRP1) in bronchial epithelium of COPD patients. Virchows Arch 2006;449:682-8.

[21] Zeitlinger M, Müller M, Joukhadar C. Lung microdialysis-a powerful tool for the determination of exogenous and endogenous compounds in the lower respiratory tract (mini-review). AAPS J 2005;7:E600-8.

[22] Brunner M, Langer O. Microdialysis versus other techniques for the clinical assessment of in vivo tissue drug distribution. AAPS J 2006;8:E263-71.

[23] Lodise TP, Preston S, Barghava V, Bryskier A, Nusrat R, Chapel S, et al. Pharmacodynamics of an $800 \mathrm{mg}$ dose of telithromycin in patients with community-acquired pneumoniae caused by extracellular pathogens. Diagn Microbiol Infect Dis 2005;52:45-52. 
[24] Tessier PR, Mattoes HM, Dandekar PK, Nightingale CH, Nicolau DP.

Pharmacodynamic profile of telithromycin against macrolide- and fluoroquinoloneresistant Streptococcus pneumoniae in a neutropenic mouse thigh model.

Antimicrob Agents Chemother 2005;49:188-94. 
Fig. 1. Plasma and tissue pharmacokinetics of telithromycin at steady state following multiple doses of $800 \mathrm{mg} /$ day (mean + standard deviation; $n=10$ ). 
Table 1

Pharmacokinetic indices of telithromycin following administration of $800 \mathrm{mg} /$ day $(n=10)^{\text {a }}$

(A) Single-dose study ${ }^{\mathrm{b}}$

\begin{tabular}{|c|c|c|c|c|c|c|}
\hline Compartment & $C_{\max }(\mathrm{mg} / \mathrm{L})$ & $T_{\max }(\mathrm{h})$ & $T_{1 / 2 \beta}(\mathrm{h})$ & $\begin{array}{l}\mathrm{AUC}_{0-24}(\mathrm{mg} \\
\mathrm{h} / \mathrm{L})\end{array}$ & $\begin{array}{l}\text { fAUC }_{0-24} \text { tissue/fAUC } \\
\text { plasma }\end{array}$ & $\begin{array}{l}\mathrm{fAUC}_{0-24} / \mathrm{MIC} \\
\mathrm{c}\end{array}$ \\
\hline Plasma (total) & $1.13(0.60-2.26)$ & $\begin{array}{l}2.7(2.0- \\
4.0)\end{array}$ & $\begin{array}{l}2.0(1.8- \\
4.7)\end{array}$ & $5.66(3.94-9.23)$ & - & - \\
\hline $\begin{array}{l}\text { Plasma (free) } \\
\text { d }\end{array}$ & $0.34(0.18-0.68)$ & $\begin{array}{l}2.7(2.0- \\
4.0)\end{array}$ & $\begin{array}{l}2.0(1.8- \\
4.7)\end{array}$ & $1.70(0.76-2.77)$ & - & $3.4(1.5-5.5)$ \\
\hline Muscle & $0.13(0.03-0.36)$ & $\begin{array}{l}3.7(2.3- \\
6.0)\end{array}$ & $\begin{array}{l}2.7(1.1- \\
6.6)\end{array}$ & $0.96(0.14-1.74)$ & $0.59(0.19-1.42)$ & $1.9(0.5-3.7)$ \\
\hline Subcutis & $\begin{array}{l}0.14(0.05-0.40) \\
*\end{array}$ & $\begin{array}{l}5.0(4.0- \\
6.0)\end{array}$ & $\begin{array}{l}3.3(1.7- \\
5.9)\end{array}$ & $1.36(0.53-3.42)$ & $0.80(0.23-2.44)$ & $2.7(1.1-6.8)$ \\
\hline
\end{tabular}

(B) Multiple-dose study

\begin{tabular}{|c|c|c|c|c|c|c|}
\hline Compartment & $C_{\max }(\mathrm{mg} / \mathrm{L})$ & $T_{\max }(\mathrm{h})$ & $T_{1 / 2 \beta}(\mathrm{h})$ & $\mathrm{AUC}_{0-24}(\mathrm{mg} \mathrm{h} / \mathrm{L})$ & $\begin{array}{l}\text { fAUC }_{0-24} \text { tissue/fAUC } \\
\text { plasma }\end{array}$ & $\begin{array}{l}\mathrm{fAUC}_{0-24} / \mathrm{MIC} \\
\mathrm{c}\end{array}$ \\
\hline Plasma (total) & $1.73(0.94-2.89)$ & $\begin{array}{l}2.8(2.3- \\
3.3)\end{array}$ & $8.6(5.9-12.8)$ & $\begin{array}{l}11.53(4.64- \\
23.57)\end{array}$ & - & - \\
\hline
\end{tabular}




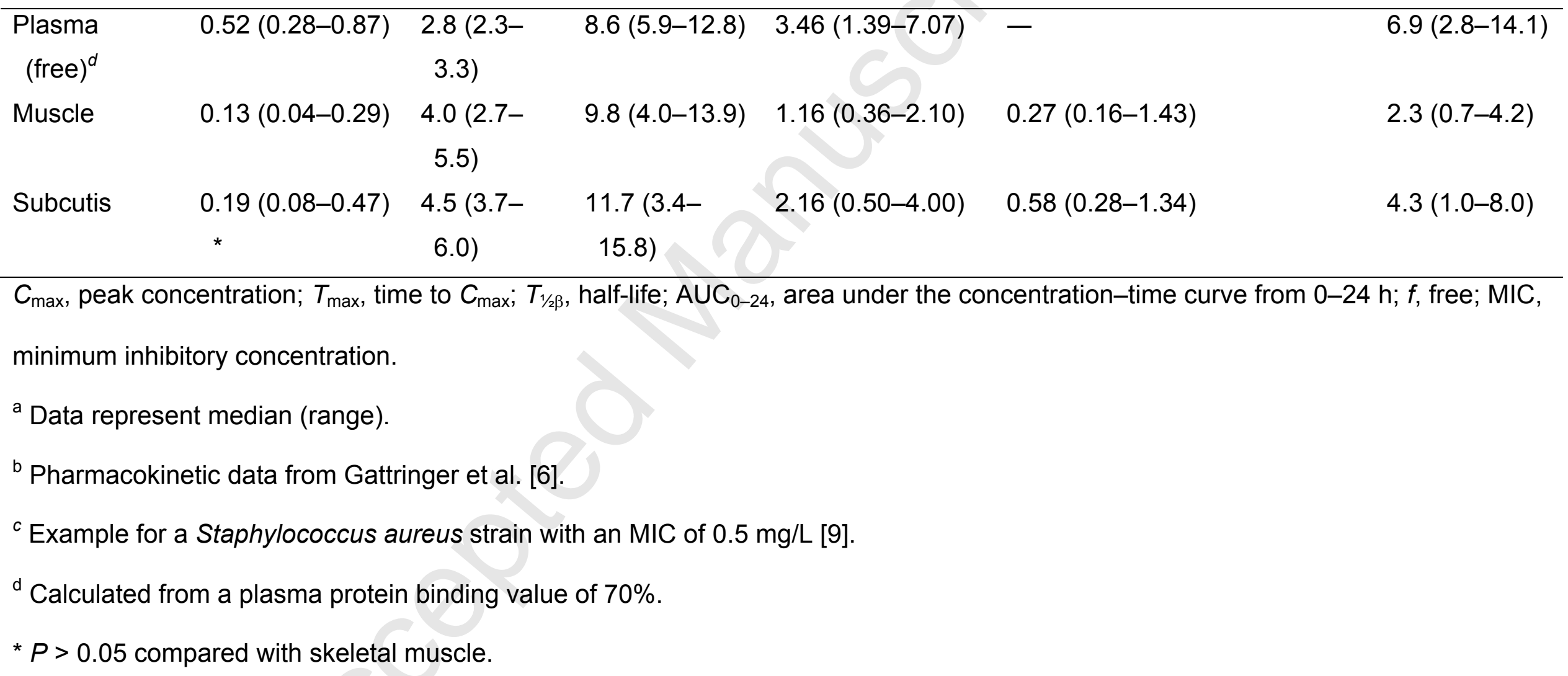

Muscle $0.13(0.04-0.29)$

4.0 (2.7$9.8(4.0-13.9) \quad 1.16(0.36-2.10)$

Subcutis

$$
0.19(0.08-0.47) \quad 4.5(3.7-\quad 11.7(3.4-
$$$$
6.0)
$$

$C_{\text {max }}$, peak concentration; $T_{\max }$, time to $C_{\max } ; T_{1 / 2 \beta}$, half-life; $\mathrm{AUC}_{0-24}$, area under the concentration-time curve from 0-24 $\mathrm{h} ; f$, free; $\mathrm{MIC}$, minimum inhibitory concentration.

a Data represent median (range).

${ }^{\mathrm{b}}$ Pharmacokinetic data from Gattringer et al. [6].

${ }^{c}$ Example for a Staphylococcus aureus strain with an MIC of $0.5 \mathrm{mg} / \mathrm{L}$ [9].

${ }^{d}$ Calculated from a plasma protein binding value of $70 \%$.

${ }^{*} P>0.05$ compared with skeletal muscle. 
Figure 1.

Plasma and tissue pharmacokinetics of telithromycin at steady-state after repetitive doses of 800 mg once daily (mean + SD; $n=10$ )

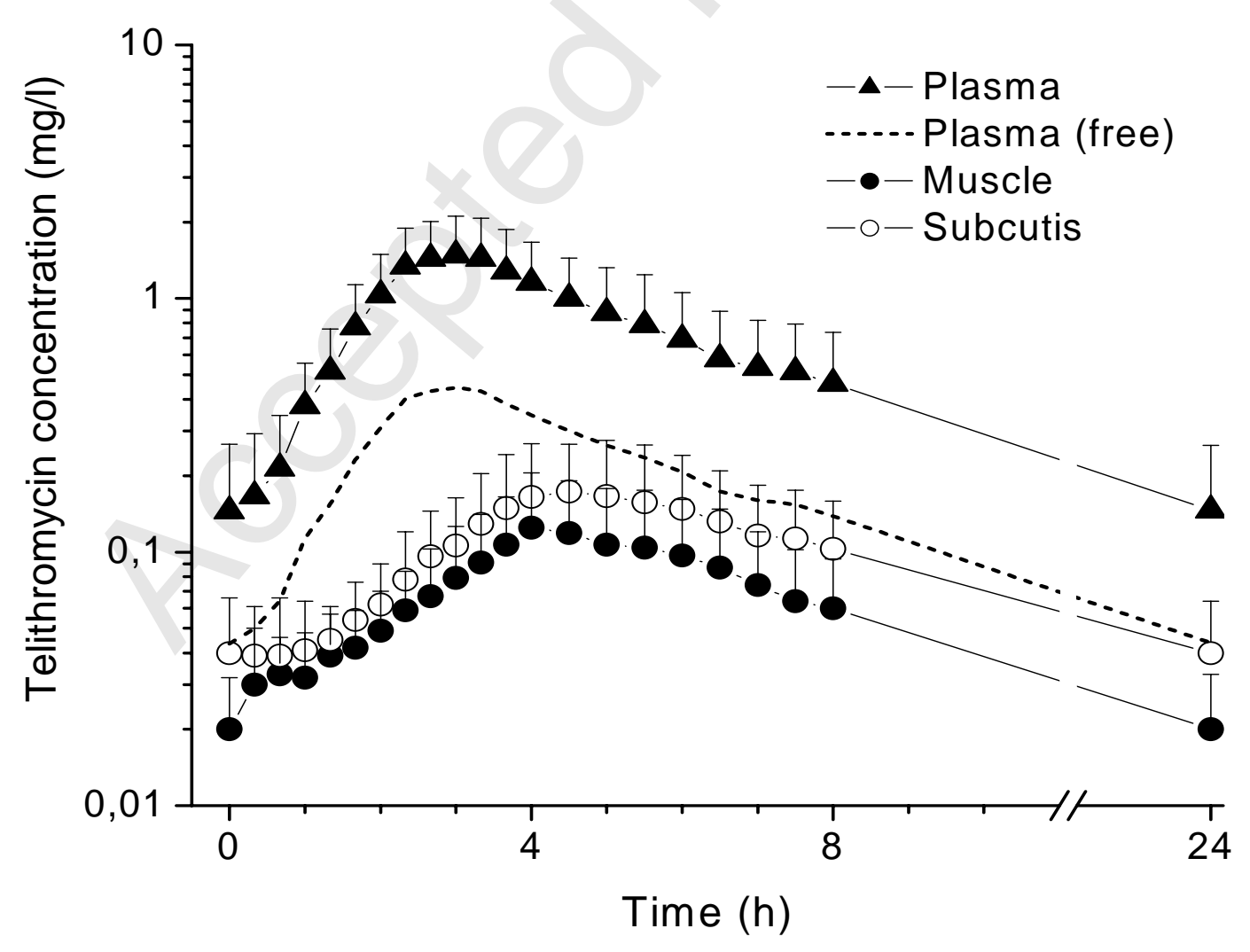

